\title{
PENERAPAN MODEL PICTURE AND PICTURE PADA PEMBELAJARAN FISIKA KELAS VII SMP NEGERI PASENAN
}

\author{
Ovilia Putri Utami Gumay ${ }^{1}$, Muhammad $\mathrm{Ali}^{2}$ \\ Sekolah Tinggi Ilmu Keguruan danPersatuan Republik Indonesia \\ (STKIP-PGRI) Lubuklinggau \\ Email: zhoulia127@gmail.com
}

\begin{abstract}
This study aims to determine the completeness of the learning outcomes of grade VII physics in Pasenan State Middle School after the picture and picture model was applied. This research method used is quasi-experimental research. The population in this study were all students in class VII.1 Pasenan State Middle School 2016/2017 Academic Year. The sample in the study consisted of one class taken randomly by drawn, namely class VII.1, which amounted to 32 students. Data collection techniques using test techniques in the form of essays amount to ten items. With an average pretest score of 43.58 and a posttest mean value of 78.93 so that there is an increase in the value of mastery learning outcomes of 35.35 , this data was analyzed using the $t$ test. Based on the results of the analysis of the final test data with a confidence level of $95 \%$, it can be t_count (6.54) and $t_{-}$(table) $(1,697)$ because $t_{-}$(count>) t_table means that Ho is rejected and Ha is accepted. learning outcomes of grade VII physics at SMP Negeri Pasenan.Penelitian ini bertujuan untuk mengetahui ketuntasan hasil belajar fisika kelas VII SMP Negeri Pasenan setelah diterapkan model picture and picture.
\end{abstract}

\begin{abstract}
Abstrak: Penelitian ini bertujuan untuk mengetahui peningkatan hasil belajar siswa kelas VII SMPN Pasenan setelah diterapkan model pembelajaran picture and picture. Metode penelitian ini yang digunakan adalah penelitian eksprimen semu. Populasi dalam penelitian ini adalah seluruh siswa kelas VII.1 SMP Negeri Pasenan Tahun Pelajaran 2016/2017. Sampel pada penelitian terdiri dari dari satu kelas diambil secara acak dengan cara diundi yaitu kelas VII.1 yang berjumlah 32 siswa. Teknik pengumpulan data dengan menggunakan teknik tes dalam bentuk essay berjumlah sepuluh butir soal. Dengan nilai rata-rata pretest yaitu 43,58 dan nilai rata-rata posttest yaitu 78,93 sehingga terjadi peningkatan nilai ketuntasan hasil belajar sebesar 35,35, data ini dianalisis dengan menggunakan uji-t. Berdasarkan hasil analisis data tes akhir dengan taraf kepercayaan $95 \%$ di dapat $t_{\text {Hitung }}(6,54)$ dan $t_{\text {tabel }}(1,697)$ karena $t_{\text {hitung }} t_{\text {tabel }}$ berarti Ho ditolak dan Ha diterima, maka diperoleh kesimpulan bahwa model picture and picture dapat meningkatkan hasil belajar fisika kelas VII SMP Negeri Pasenan.
\end{abstract}

(C) 2019 Physics Education Department, STKIP PGRI Lubuklinggau, Indonesia

Kata Kunci : Hasil Belajar, Model Picture and Picture

\section{PENDAHULUAN}

Pendidikan memegang peranan penting dalam usaha untuk mencerdaskan kehidupan bangsa. Hal dilihat dari kemajuan ilmu pengetahuan dan teknologi yang semakin menutut sumber daya manusia, oleh sabab itu mutu pendidikan harus ditingkatkan.Guru sebagai pengajar mempunyai tanggung jawab atas terselenggara proses belajar mengajar, selain itu guru di tuntut membawa perubahan dalam pembelajaran.Hakikat bila suatu kegiatan direncanakan terlebih 
dahulu, maka tujuan dari kegiatan akan lebih terarah dan lebih berhasil, pada pembelajarn fisika pembaharuanpembaharuan juga dilakukan, baik yang menyangkut model, materi, media maupun faktor-faktor lainnya yang dapat menunjang terciptanya tujuan yang di inginkan.

Istarani (2012:7) mengatakan bahwa Picture and picture merupakan suatu rangkaian penyampaian materi ajar yang menunjukan gambar-gambar konkrit kepada siswa sehingga siswa dapat memahami secara jelas kepadanya. Menurut Kiranawati (2011:4) model Picture and picture adalah suatumodel belajar yang menggunakan gambar dan dipasangkan atau diurutkan yang logis. Menurut Kurniasih (2015:44) model pembelajaran Picture and Picture adalah merupakan model pembelajaran kooperatif atau mengutamakan adanya kelompokkelompok dengan menggunakan media gambar yang dipasangkan atau diaturkan menjadi urutan yang logis. kepada siswa tentang dasar pemikiran gambar tersebut.

Adapun langkah-langkah pelaksanaan model pembelajaran picture and picturemenurutAqib (2013:18) terdapat 7 langkah-langkah yaitu :
1) Guru menyampaikan kompetensi yang ingin dicapai

2) Menyajikan materi sebagai pengantar

3) Guru menunjuk/ memperlihatkan gambar-gambar kegiatan berkaitan dengan materi.

4) Guru menunjuk/ memanggil siswa secara bergantian untuk memasang/ mengurutkan gambar-gambar menjadi urutan logis

5) Guru menanyakan alasan/dasar pemikiran dari urutan gambar tersebut.

6) Dari alasan atau urutan gambar tersebut guru mulai menanamkan

7) Konsep/materi sesuai dengan kompetensi yang ingin di capai.

8) Kesimpulan/rangkuman.

Menurut Kurniasih (2015:46) langkahlangkah model picture and pictureadalah sebagai berikut :

1) Guru menyampaikan tujuan pembelajaran yang ingin dicapai

2) Guru menyampaikan pengantar pembelajaran,

3) Guru memperlihatkan gambar-gambar yang telah disiapkan

4) Siswa dipanggil secara bergantian untuk mengurutkan gambar menjadi urutan logis 
5) Guru menanyakan alasan logis urutan gambar, setelah gambar menjadi/guru harus bisa menanamkan konsep atau materi sesuai dengan kompetensi yang ingin dicapai.

Berdasarkan pendapat di atas maka disimpulkan model Picture and picturemerupakan model kooperatif menggunakan media gambar yang mempermudahkan guru, menjelaskan materi di depan kelas kepada siswa, guru menempelkan gambar sesuai dengan materi yang di pelajari, guru memanggil salah satu siswa untuk maju ke depan dan menjelaskan gambar lalu menempelkan gambar dengan benar guru menanyakan kepada siswa dasar pemikiran gambar tersebut,guru melihat kemampuan siswa dalam berpikir.

Kurniasih (2015:44) mengatakan bahwa ciri-ciri model picture and picturesebagai berikut :
1) Aktif
2) Inovatif
3) Kreatif
4). Menyenangkan

\section{METODE PENELITIAN}

Metode yang digunakan penelitian ini eksprimen semu, model Picture and picture merupakan model pembelajaran kooperatif yang menggunakan media gambar yang mempermudahkan guru, menjelaskan materi di depan kelas kepada siswa, guru menempelkan gambar dengan materi yang pelajari, guru memanggil salah satu siswa untuk maju ke depan dan menjelaskan dengan benar, guru menanyakan kepada siswa dasar pemikiran gambar tersebut.

\section{HASIL DAN PEMBAHASAN}

Penelitian ini dilaksanakan di SMP Negeri Pasenan dimulai dari tanggal 10 Nopembersampai dengan 8 Desember 2016. Dalam penelitian ini menggunakan satu kelas sampel yaitu kelas VII.1 dengan jumlah siswa 32 yang di ambil secara acak. Adapun jumlah siswa kelas VII seluruhnya 64 siswa dari dua kelas yang ada. Pada penelitian ini proses pembelajaran menggunakan model Picture and picture.

Pelaksanaan penelitian dilaksanakan selama lima kali pertemuan yaitu dengan rincian satu kali tes uji coba instrumen di kelas VIII di luar sampel. Satu kali tes kemampuan awal (Pretest), dua kali mengadakan pembelajaran atau pemberian pemberlakuan dan satu kali melakukan tes kemampuan akhir (Post-test). Pemberian 
pretest untuk mengetahui kemampuan awal siswa, materi suhu dan pengukurannya.

Kemampuan pretest adalah kemampuan yang dimiliki siswa sebelum mengikuti pembelajaran di kelas. Setelah kemampuan pretest siswa diketahui, maka dilakukan kegiatan pembelajaran dengan menggunakan model Picture and picture. Kegiatan ini dilakukan sebanyak dua kali pertemuan, pada akhir penelitian dilakukan post-test untuk mengetahui kemampuan akhir siswa. Kemampuan akhir siswa adalahkemampuan siswa dalam ranah kognitif dalam penguasaan materi suhu dan pengukuran yang merupakan hasil belajar siswa setelah mengikuti proses pembelajaran.

Pelaksanaan Pretest dilakukan tanggal 17 November 2016 diikuti oleh 30 siswa pada kelas VII.1. Pelaksanaan pre-test dilakukan untuk dapat mengetahui kemampuan awal siswa sebelum diberikan model Picture and Picture materi suhu dan pengukuran. Soal pretest yang digunakan berbentuk essay terdiri 10 soal yang sudah diuji terlebih dahulu di uji coba pada kelas di luar sampel.

Berdasarkan hasil analisisrekapitulasi pada soalPretest siswadalam penerapan model picture and picture pada kelas VII.1
SMP Negeri Pasenan Tahun Pelajaran 2016/2017. Maka dapat dilihat pada Tabel 4.1.

Tabel 4.1. Rekapitulasi Hasil Pretest Siswa dalam penerapan Model Picture and picture

\begin{tabular}{cc}
\hline Nilai Rata-rata & 43,58 \\
\hline Nilai Tertinggi & 71 \\
Nilai Terendah & 10 \\
Siswa yang Tuntas & 4 Siswa \\
Siswa yang belum Tuntas & 26 Siswa \\
\hline
\end{tabular}

Post-test dilaksanakan hari Jum'at tanggal 8 Desember 2016 diikuti oleh 30 siswa pada kelas VII. Post-test dilakukan untuk dapat mengetahui hasil belajar siswa setelah mengikuti model picture and picture. Dan Post-test dilakukan pada pertemuan terakhir soal yang digunakan berbentuk uraian (essay) yang terdiri sepuluh soal. Perbandingan nilai rataratahasil belajar siswa setelah melakukan penerapan Model Picture and picture. Makadapat di lihat pada

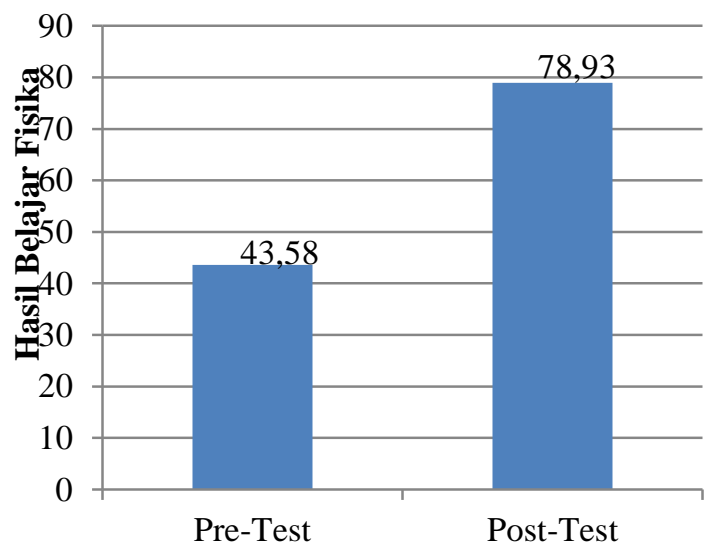

Grafik. 4.1. Grafik Pretest dan Post-test 
Berdasarkan gambar grafik 4.1. di atas maka dilihat nilai rata-rata Pretest yaitu 43,58 dan Post-test yaitu 78,93 dengan selisih 35,35. Maka disimpulkan setelah penerapan model picture and picture hasil belajar siswa mengalami peningkatan secara signifikan.

Data penelitian ini diperoleh dari hasil post-test yang digunakan untuk menguji hipotesis secara statistik hipotesis danpenelitian yang berbunyi "Hasil belajar fisika kelas VII. SMP Negeri Pasenan setelah penerapan Model Picture and Picture secara signifikan tuntas". Sebelummenguji hipotesis dan di analisis terlebih dahulu dengan uji normalitas data. Berdasarkan hasil dari perhitungan nilai rata-rata dan simpanganbakunya diperoleh nilai rata-rata siswa $(\vec{x})$ pada pretest sebesar 43,58dan post-test sebesar 78,93 dan Simpangan baku pretest sebesar 17,41 dan post-test 0,24. Adapun rekapitulasi hasil perhitungan nilai rata-rata dan simpangan baku tes akhir, maka dapat di lihat pada Tabel 4.2.

Tabel 4.2. Rekapitulasi Hasil Perhitungan Nilai Rata-rata dan Simpangan Baku Data Pretest dan Post-Test

\begin{tabular}{lcc}
\hline \multicolumn{1}{c}{ Tes } & $\begin{array}{c}\text { Nilai } \\
\text { Rata-rata }\end{array}$ & Simpangan Baku \\
\hline $\begin{array}{l}\text { Tes Awal } \\
\text { (Pretest) }\end{array}$ & 43,58 & 17,41 \\
$\begin{array}{l}\text { Tes Akhir } \\
(\text { Post-Test })\end{array}$ & 78,93 & 9.24 \\
\hline
\end{tabular}

a) Uji Normalitas

Uji normalitas yang bertujuan untuk mengetahui apakah kelompok data hasil ini berdistribusi normal atau tidak. Maka dapat digunakan uji normalitas dan uji kecocokan chi-kuadrat $\left(x^{2}\right)$. Berdasarkan ketentuan pada perhitungan data statistik mengenai uji normalitas data.taraf $\alpha=$ 0,05 jika $x^{2}{ }_{\text {hitung }}<x^{2}{ }_{\text {tabel }}$ maka disimpulkan data berdistribusi normal. Data di analisis normal adalah data post-test. Analisis kurva maka di lihat pada grafik 4.2 .

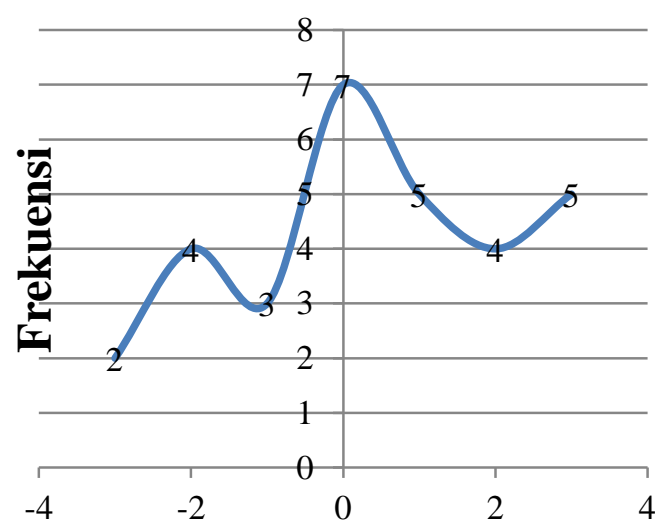

Grafik 4.2. Analisis Kurva Normalitas

Berdasarkan kurva normalitas di atas maka rekapitulasi hasil uji normalitas dapat di lihat pada Tabel. 4.3.

Tabel 4.3. Rekapitulasi Hasil Uji Normalitas

\begin{tabular}{ccccc}
\hline Data & $\boldsymbol{x}^{2}$ Hitung & Dk & $\boldsymbol{x}^{2}$ Tabel & $\begin{array}{c}\text { Kesimp } \\
\text { ulan }\end{array}$ \\
\hline $\begin{array}{c}\text { Post- } \\
\text { Test }\end{array}$ & 5,68 & $10-1$ & 11,070 & Ha \\
\hline
\end{tabular}


Berdasarkan pada Tabel 4.3. Menunjukan rekapitulasi hasil uji normalitas $x_{\text {Hitung Post-test adalah 5,68 }}^{2}$ dan $x^{2}{ }_{\text {Tabel }}$ Post-test adalah 11,070 maka $\left(x_{\text {Hitung }}^{2}<x_{\text {Tabel }}^{2}\right)$ Pengujian uji normalitas dengan chi-kuadrat $\left(x^{2}\right)$ maka disimpulkan bahwa data tes akhir berdistribusi normal dengan taraf kepercayaan $=0,95$.

\section{b) Uji Hipotesis}

Berdasarkan hasil uji normalitas maka di dapat hasilpretest dan post-testadalah normal dan simpangan baku populasi tidak diketahui oleh karena itu dapat di uji hipotesis, uji yang digunakan data pre-test dan post-test adalah uji-t.Untuk menguji hipotesis penelitian, yang diperlukan hipotesis statistik hipotesis penelitian adalah sebagai berikut :

$\mathrm{H}_{\mathrm{a}}: \mu_{0} \geq 66=$ Rata-rata nilai hasil belajar fisika kelas VII SMP Negeri Pasenan setelah penerapan model picture and picture lebih dari atau sama dengan 66.

$\mathrm{H}_{\mathrm{o}}: \mu_{0}<66$ = Rata-rata nilai hasil belajar fisika kelas VII SMP Negeri Pasenan setelah penerapan model picture and picture kurang dari 66.

Berdasarkan data perhitungan rekapitulasi hasil uji hipotesis maka dapat di lihat pada Tabel. 4.4.
Tabel. 4.4. Rekapitulasi Hasil Uji HipotesisPretest dan Post-Test

\begin{tabular}{cccccc}
\hline Data & $\mathrm{t}_{\text {hitung }}$ & $\mathrm{dk}$ & $\boldsymbol{\alpha}$ & $\mathrm{t}_{\text {tabel }}$ & $\begin{array}{c}\text { Kesimpu } \\
\text { lan }\end{array}$ \\
\hline $\begin{array}{c}\text { Pret } \\
\text { est }\end{array}$ & 6,54 & 10 & 0,05 & 1,697 & $\begin{array}{c}\text { Ha. } \\
\text { Diterima } \\
\text { Post- } \\
\text { Test }\end{array}$ \\
7,58 & 10 & 0,05 & 1,697 & $\begin{array}{c}\text { Ha. } \\
\text { Diterima }\end{array}$ \\
\hline
\end{tabular}

Dari tabel di atas maka uji hipotesis dapat di lihat bahwa hasil $t_{\text {hitung }}=6,54$

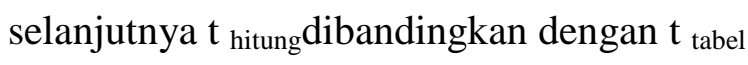
pada daftar distribusi $\mathrm{t}$ dengan $\mathrm{dk}=\mathrm{n}-1=$ $30-1=29, \alpha=0.05$ maka diperoleht tabel $=1,697$ maka $\mathrm{t}$ hitung $(6,54)>\mathrm{t}_{\text {tabel }}(1,697)$. Hal ini berarti $\mathrm{H}_{\mathrm{o}}$ ditolak dan Haditerima. Dengan hipotesis yang diajukan dalam penelitian ini dapat diterima kebenarannya dengan kata lain "Hasil belajar fisika siswa kelas VII SMP Negeri Pasenan Tahun Pelajaran 2016/2017 setelah penerapan model picture and picture secara signifikan tuntas.

Penelitian ini dilakukan di SMP Negeri Pasenan Kecamatan STL Ulu Terawas yang Kab. Musi Rawas yang bertujuan untuk mengetahui hasil belajar fisika siswa kelas VII SMP Negeri Pasenan Tahun Pelajaran 2016/2017. Setelah diterapkan model picture and picture. Penelitian ini merupakan penelitian eksprimen semu (quasi eksprimen)yang melibatkan satu kelompok sampel. Sampel dalam penelitian 
ini adalah satu kelas yang diambil secara acak yaitu kelas VII.1 yang terdiri 32 siswa.

Berdasarkan dari hasil penelitian yang dilakukan di SMP Negeri Pasenan yang terdiri dari 32 siswa kelas VII.1 sebagai kelas eksprimen,terdapat peningkatan hasil belajar fisika.Hal ini disebabkan peneliti melakukan proses pembelajaran menggunakan model Picture and Picture. Model ini menggunakan media gambar sesuai materi dan media gambar dijelaskan oleh guru di depan kelas. Selanjutnya guru meminta siswa untuk mengurutkan gambar tersebut menjadi urutan yang logis dan benar, guru menanyakan kepada siswa alasannya gambar tersebut kemudian guru dan siswa membuat kesimpulan tentang materi tersebut.

Pertemuan pertama sebelum diterapkannya Model Picture and Picture terlebih dahulu diberikan soal pretest. Pretest bertujuan untuk mengetahui kemampuan awal siswa. Pada pertemuan pertama ini siswa belum aktif dalam menerima pelajaran, belum terbiasa dengan model yang diberikan, serta belum terbiasa dengan di bentuknya kelompok belajar. Selain itu ada beberapa siswa yang merasa tidak cocok dengan siswa lain dalam kelompoknya. Sehingga sekarang terjadi sedikit perselisihan. Hasil dari perhitungan Pretest sebelum diterapkan model picture and picture. Hasil di capai nilai tertinggi 71 , nilai terendah 10 , nilai rata-rata sebesar 43,58 siswa yang tuntas 4 siswa dan belum tuntas 26 siswa dengan KKMyang di tetapkan sekolah 66.Setelah diberikan perlakuan dengan menerapkan model pada pertemuan terakhir melakukan evaluasi diberikan melalui Post-test.Evaluasi inibertujuan untuk mengetahui kemampuan siswa setelah belajar model picture and picture. Dimana hasil perhitungan nposttest adalah nilai tertinggi 94 , nilai terendah 63, nilai rata-rata post-test 78,93 dan siswa yangtuntas 26 Siswa dan 4 siswa belum tuntas. rentang nilai adalah 31 .

Perbedaan hasil belajar siswa sebelum dan sesudah diberikan perlakuan dengan menggunakan model Picture and pictureternyata hasilnya lebih baik setelah diberi perlakuan dan diperoleh nilai ratarata pretest sebesar 43,58.Nilai rata-rata post-test sebesar 78,93. Hasil post-test mengalamipeningkatan sebesar 35,35 dari hasil pretest. Saat post-test ini 26 siswa $(86,67 \%)$ telah tuntas dan hanya 4 siswa $(13,37 \%)$ yang belum tuntas. 


\section{KESIMPULAN}

Berdasarkan hasil penelitian dan analisis data yang dilakukan peneliti, maka dapat disimpulkan bahwa hasil belajar fisika siswa kelas VII SMP Negeri Pasenan Tahun Pelajaran 2016/2017 setelah diterapkan model picture and picture secara signifikan tuntas. Nilai rata-rata pretest sebesar 43,58 dan nilai rata-rata post-test sebesar 78,93 sehingga nilai rata-rata mengalami peningkatan sebesar 35,35 dan persentase jumlah siswa yang mengalami sebesar 73,34 \% dan persentase jumlah siswa yang tuntas sebesar 86,67\% dan belum tuntas $13,33 \%$.

\section{DAFTAR PUSTAKA}

Aqib, Zainal. 2013. Model-Model, Media \& Strategis Pembelajaran Kontektual (Inovatif). Bandung:Yrama Widya Istarani. 2012. Model Pembelajaran Inovatif. Medan:Media Persada. Jurnal (JIM) Pend.Fisika,1.(3) Juli 2016.(4248). Tgl. 22 Agustus 2017

Kurniasih, Berlin. 2015.Ragam PengembanganModel Pembelajaran untuk MeningkatkanProfesionalisme Guru. Jakarta:Kata Pena

Kiranawati.2011.Model Pembelajaran Picture and picture berpengaruh berbantu kemampuan Berpikir Kreatif Siswa dalam pembelajaran IPAkelas V SD Gugus Budi Utomo. $e$ jurnal Mimbar PGSD Universitas Pendidikan Ganesha :2(1):4 